\title{
The Retrospect of Modern China on Islamic Studies - Centered on People, Institutions and Their Academic Activities
}

\author{
Alimu Tuoheti ${ }^{1}$ \\ ${ }^{1}$ Tohoku University, Japan \\ Correspondence: Prof. Alimu Tuoheti, Tohoku University, Japan. \\ Received: August 2, 2021 \\ Accepted: August 28, 2021 \\ Available online: August 30, 2021 \\ doi:10.11114/ijsss.v9i5.5338 \\ URL: https://doi.org/10.11114/ijsss.v9i5.5338
}

\begin{abstract}
The academic history of Islam in China. It not only refers to the academic history of Chinese scholars' research on Chinese Islam, but also includes the carding of various researches and achievements of Chinese scholars on foreign Islam and Muslims. This includes the study of Islamic classics such as Koran and Hadith, History, Pedagogy, Philosophy, Politics, Society and Culture. Islam and Muslims in different regions of foreign countries also have different characteristics, and the research methods also respect this aspect of attention. On the origin of academic history: according to the author's own and previous research results, it can be concluded that academic research with contemporary significance began at the beginning of the 20th century. Under the background of the introduction of Western learning to the East, modern academic research methods also affected the research field of Islam in China. There are four imams with high academic level, such as Ha Decheng, Wang Jingzhai, Da Pusheng and Ma Songtin. There is also Chen Hanzhang, Chen Yuan and Chuan Tongxian non-Muslim scholars joining the ranks of Islamic researchers. There was little research before the 20th century. The year 2000 can be regarded as the dividing line in the evolution of modern Islamic academic history. The period from the beginning of the 20th century to the founding of new China can be regarded as the beginning period. The period from the founding of new China to the reform and development can be regarded as the initial period. During this period, due to various political movements and other reasons, China's Islamic academic history and many other fields suffered setbacks such as stagnation to varying degrees. The period from reform and development to 2000 can be regarded as the prosperous period of Islamic academic research in contemporary China. During the period from 2001 to now, the subject consciousness is clear and the research methods are diversified. Many industries and scholars have actively participated in this research field, that is, using the theories and methods of religion, ethnology, anthropology, sociology, history, philosophy, linguistics, culture, politics and other disciplines to systematically study the historical, political, economic, cultural and other phenomena of Islam and Muslims, so as to lay a foundation for the further development of China's Islamic research.
\end{abstract}

Keywords: modern China, Islamic studies, people, institutions, academic activities

\section{Introduction}

Islam in China has a history stretching back over 1300 years. Introduced during the Tang dynasty, the religion was also spread through the Song, Yuan, Ming, and Qing dynasties, undergoing different stages of development. During the Tang dynasty period, Chinese Muslims were confined to just one area, but the northwest border of the Yuan dynasty was in an open state, conducive to the spread and development of Islam in China. Unlike during the period of the Tang dynasty, these Muslims lived all over China: "In the Yuan dynasty, there were many people who lived in Gansu". The social cells of Islam increased dramatically. In the Ming dynasty, Islam finally had a relatively fixed name "Huihui Jiao", "Huigui Jiaomen", and "Hui Jiao", etc. In the Ming dynasty, Islam finally had a solid social conveyor "Huihui people". This is a milestone event in the development of Islam in China. The formation of the Muslim community in the Ming Dynasty marked the end of the stage of Islamic communication in China. In this respect, Sha Zongping writes: "At the end of the Yuan dynasty and the beginning of the Ming dynasty, based on common belief and common customs of life, the Hui nationality, today's Hui nationality, was formed with Islam as the link. The formation of the Hui nationality

\footnotetext{
${ }^{1}$ Biography of the western regions in the history of the Ming Dynasty
} 
means that Islam has a solid national foundation in Northwest China, just like in Xinjiang." Generally speaking, Muslim society emerged. The transmitting force of Islam in the spreading period (Tang, Song, and Yuan dynasties) was the individual, while the spreader in the Ming period was the community. The community played an important role in the religion's development in the Qing dynasty. Then, the Qing dynasty was marked by a more predominant Islam, so the degree of social infiltration was more profound. Saliently, in the early Qing dynasty, the early history of localization and contextualization of Islam in China was over.

During the Ming and Qing dynasties, a group of scholars engaged in the study of Islam appeared, marking an important point in the history of Chinese Islam. They wrote in Chinese on the Islamic doctrines and cultural thinking, called "Yi Ru Quan Jing" (interpreting scriptures by Confucianism), "Yuan Ru Ru Men" (assisting Confucianism into Hui), "Fu Ru Yi Xing" (attaching Confucianism to practice), or "Yi Ru Jie Hui" (interpreting Hui by Confucianism). Their works are rich and wide-ranging. According to Bai Shouyi, the activity of Chinese Islam scholars in the Ming and Qing dynasties is divided into two stages: "From Wang Daiyu to Liu Zhi, is one stage. Ma Dexin and Ma Lianyuan are another stage. In the first stage, Jinling is the main setting for translation and expression, and its content is either a special translation or a special description of a theoretical system. Its interests are mostly limited to religious philosophy and the system of religious canons." 3

These works embody an ideological, theoretical system. Logical thinking, theoretical discourse, and values all apply Confucianism to explain Islamic doctrine. Spanning more than 1350 years, it can be said that the understanding and research of Islam by Chinese scholars, including Chinese Muslim scholars, actually includes multi-perspective and multi-dimensional research processes such as "external description" and "internal interpretation", "objective transcendence", and "subjective intervention". Their work constitutes a forerunner of modern research. In the 20th century, the revolution of 1911 overthrew the rule of the Qing dynasty, ushering China into a new historical period, that of the Republic of China. In a short period of little more than 40 years, great changes took place in China's social politics, economy, and culture: the overthrow of the autocratic monarchy, the abolition of the bureaucratic system, rituals, and the imperial examination system, and the gradual transition of China from a semi-feudal, semi-colonial society to a modern one. This period was not only one of turbulence, internal and external troubles, but was also reflective of the growing revolutionary movement. Since Chinese Muslims dispensed with the high-pressure policy of the Qing dynasty and were influenced by revolutionary thought, they gradually emerged from being a closed state, and their national consciousness gradually increased. They began to demand political equality, the improvement of their economic life, cultural and educational development, and freedom of religious belief. During this period, due to the development of social and sectarian contradictions, certain groups spread the religious ideas and literature of the Wahhabi school, founding the Ihwani school in Gansu, Qinghai, and Ningxia in the northwest, and later spread it to Henan, Shandong, Hebei, and Xinjiang. This was the second sectarian differentiation of Islam in China since the introduction of Sufism in the late Ming and early Qing dynasties. After these two divisions, the pattern of the modern Chinese Islamic factions was apparent.

By 1949, the components of Islam in China were Gedi, Sufism Menhuan (including hufeiye, jiadilinye, zhehlinye, and kubulinye), Xidaotang, Ihwani, Selefiye, and Yichan. Most Chinese Muslims belong to the Suni Hanafi school; the basic beliefs and doctrines of the various schools are the same, but some differences exist in the details of certain disciplines and rituals. Under the influence of the national bourgeoisie in modern China, a group of Muslim scholars advocated the reform of religious education, the implementation of "two links of scriptures", and the establishment of new schools. This promoted the transformation of Chinese Muslim Temple Scripture education to modern education. When Islam was introduced into China, due to the different era, way of life, social and historical environment, and cultural background of various ethnic areas, Islam and its Chinese (e.g., Hui) and Turkic (e.g., Uyghur) cultures were formed through the process of transmission, development, and evolution, producing two major systems of Islam with national characteristics. Today, as an international and national religion, Islam in China has become one of the five major religions in the country, and has had a certain historical impact on, and exercises contemporary influence in, the Chinese nation.

\section{People, Institutions and Academic Journals}

\subsection{People}

Combing the "Academic history of Islamic Studies in modern China" should start from the four imams who have made great contributions to the cause of Islam. The four major Muslim scholars are

\footnotetext{
${ }^{2}$ Sha Zongping,2004, "Chinese Islamic Studies", Peking University Press, P. 49.

${ }^{3}$ Bai Shouyi, 2000, “A brief history of Chinese Islam”, Ningxia people's publishing house, p.75.
} 
Ha Decheng (1888-1943) was born in Nanzheng. He made a pilgrimage to Mecca and studied in Egypt. In 1924, he returned to China as Imam of the mosque on Zhejiang Road in Shanghai, and initiated the establishment of "Chinese Muslim society" with Ma ganghou. At the same time, the journal "MONTHLY" was founded to expound the Islamic doctrine. 28 years in Shanghai to participate in the initiation and establishment of "Islamic normal school" as Dean of educational affairs. He also organized Ma Jian and others to work on the translation of the "Koran" and Islamic culture.

Wang Jingzhai (1879-1949) was born in Tianjin. In 1922, he went abroad to study, studied at Al-Azhar University in Egypt, and studied in Turkey, India and other places. After pilgrimage in 1923, he returned to China and founded China Arab University in Tianjin. In 1927, he hosted the "YIGUANG" monthly. Later, he went to Beijing jiaozi Hutong Mosque as Imam. In 1937, he initiated the establishment of "Chinese Hui Anti-Japanese Association" in Henan Province. There are many translated works, such as the interpretation of the Koran, "Arabic Chinese Dictionary", "WEIGAYE" etc.

Da Pusheng (1874-1965) was born in Liuhe. In 1907, he and Wang Kuan founded the Muslim normal school in Beijing Niujie Mosque. He was the president of Shanghai Islamic normal school in 1928. In 1952, he participated in the initiation of the Chinese Islamic Association and was elected as the deputy director. He was also the dean of the Islamic Scripture Academy.

Ma Songting (1895-1992), born in Beijing, is a student of Dapu. He once went to Mecca for pilgrimage, and after returning to China, he served as Imam of Xidan mosque in Beijing. In 1925, Chengda normal school was established with Jinan. He once founded Yuehua magazine and published "YUEHUA". He went to Egypt for further study. He once served as deputy director of China Association for Iraq and vice president of Islamic Economic College. He is the author of Islam and life.

These Muslim Imam scholars are knowledgeable, familiar with Arabic and Persian Islamic classics. Some of them are fluent in English and have many translations. They have unique views on the calendar and Chinese Islamic translations. In addition to these religious workers, Muslim scholars also engage in Islamic related research in universities and research institutions

Jinjitang (1908-1978), a historian and educator of Islam in modern China. Hui nationality. Beijing Tongxian people. The main papers are more than 10 , such as "the historical problems of Chinese Islam", "the miscellaneous knowledge of religious sects", "The theory of Muslim nationality", and "The five hundred years of Laici mosque".

Bai Shouyi (1909-2000), a Hui nationality, is a historian, educator and social activist. He put all his life's research into the field of history, and made outstanding achievements in the history of Islam and Hui nationality in China. "The outline of Chinese general history", edited by him, was published in 1980.

Ma Jian (1906-1978), a modern Chinese Islamic scholar, is a professor of Oriental Language and Literature Department of Peking University. His works include "History of Arab philosophy", "Arabian Peninsula", "General history of Arab", "Brief history of Arab", "Overview of Chinese Islam", "Academic movement of Muslim sages", "Status of Arabic in international politics", "Sword of Muhammad", "Brief biography of the holy Muhammad", "Arabic Chinese dictionary", etc. His independent translation was published in the Chinese version of the "Koran".

At the beginning of the 20th century, most of them were Chinese Muslim scholars, but there were also non-Muslim scholars such as Chen $\operatorname{Tan}^{4}$ and Chen Hanzhang ${ }^{5}$. The research results of these scholars have been widely recognized by the academic community. Their research focused on the history and classics of Islam in China. Later, influenced by the background of the eastward spread of Western learning, such as textual research historiography, Marxist historiography and Western positivist historiography, they began to use new methods to study the history, doctrine and law of Islam and Muslims abroad, it also involves the contemporary Islamic and Muslim issues and many other fields.

With their unremitting efforts, they have established a solid theoretical and practical foundation for the establishment of various research institutions and the emergence of many outstanding scholars after the reform and opening up.

\subsection{Institutions}

In 1964, the Institute of world religions of the Chinese Academy of Social Sciences was established as a state-level specialized institution for religious academic research, with eight research rooms for Buddhism, Christianity, Islam and

${ }^{4}$ Chen Tan, 1927, "A brief introduction to the history of Islam in China", the first edition of the monthly journal of Sinology of the Institute of Peking University, Vol. 25, No. 1, and the later edition of the Oriental journal, Vol. 25, No. 1, 1928 , has been renamed since.

${ }^{5}$ Chen Hanzhang, 1926, "History of Chinese Islam”, historiography and geoscience, Vol.1, pp.16-22. 
Taoism, as well as religious research magazines and scientific research offices. Among them, the Islamic research office is the only academic research institution engaged in the study of Islam and its related topics, which can be regarded as the beginning of a new stage. However, it is a pity that many Chinese academic research institutions, including Islamic Studies, have suffered setbacks for more than ten years. Until the reform and opening up, new research institutions will continue to emerge.

The departments set up by the higher authorities and the sources of funds of the research institutions can be divided into the following categories

\begin{tabular}{|l|l|}
\hline governmental agency & $\begin{array}{l}\text { Department of Islam, Institute of world religions, Chinese Academy of Social Sciences; } \\
\text { Research on Islam of State Bureau of Religious Affairs }\end{array}$ \\
\hline $\begin{array}{l}\text { Social science research } \\
\text { institutions }\end{array}$ & $\begin{array}{l}\text { Ningxia Institute of Social Sciences and Institute of Islamic states in the Middle East; } \\
\text { Gansu Institute of Nationalities; } \\
\text { Institute of religion, Xinjiang Academy of Social Sciences }\end{array}$ \\
\hline $\begin{array}{l}\text { Scientific research } \\
\text { institutions in Colleges } \\
\text { and Universities }\end{array}$ & $\begin{array}{l}\text { Department of religious studies, School of philosophy and religion, Central University for } \\
\text { nationalities, and related research departments, School of nationalities and society; The } \\
\text { related research departments of Northwest University for nationalities; Southwest University } \\
\text { for nationalities; Central South University for nationalities; Qinghai University for } \\
\text { nationalities, etc. } \\
\text { Department of philosophy, Peking University; Shanghai Institute of foreign languages, } \\
\text { Middle East Research Institute of Northwest University; Yunnan University; Xinjiang } \\
\text { University; Xinjiang Normal University and other relevant research departments of colleges } \\
\text { and universities. }\end{array}$ \\
\hline nongovernmental & $\begin{array}{l}\text { Xi'an Islamic Culture Research Association and other folk social and cultural research } \\
\text { academic activities. }\end{array}$ \\
\hline
\end{tabular}

Islam Research Office, Chinese Academy of Social Sciences, among them, its research scope includes Islamic history, Islamic Sharia, Sufism, Chinese Islam, Islam and international issues, ethnic issues and so on. It takes a leading position in the field of domestic Islamic research and has great influence in the world. The Ningxia Institute of Social Sciences, with their efforts, they founded the Quarterly "Journal of Hui Muslim Minority Studies" in 1991, which is still influential today. One of the representative's achievements is the establishment of the editorial department of "The Encyclopedia of Hui nationality in China". Many research results have been published. In Gansu Province, there is the Provincial Institute for nationalities. Established in 1959, the Institute is a scientific research institution specializing in ethnic and religious issues in Gansu and Northwest China. After the founding of the Institute for the study of nationalities, it organized forces to carry out a more systematic survey of the ethnic minorities in Gansu Province, collected a lot of valuable first-hand information, and made a lot of fruitful work in the cause of ethnic studies. He has completed the "Five series of Chinese Minority Issues" $^{6}$ issued by the National Committee for democracy and people's livelihood, and has successively compiled and published monographs and anthologies such as "Collection of paintings in China's ethnic minority areas"7"Research on Muslim social problems in Northwest China" ${ }^{8}$. In Xinjiang, there are mainly Xinjiang folk culture research center of Xinjiang University and Xinjiang Islam research center of Xinjiang Normal University. The folk culture research center was established in 2007 on the basis of the folklore teaching and research section of the College of humanities. The center is characterized by using the latest foreign folklore theory as the basis, specializing in Turkic ethnic groups, Islam and culture related research.

\subsection{Academic journals}

In the course of many years of research, many Chinese research institutions and academic units in the field of Islam and

\footnotetext{
“"China's ethnic minorities", "A series of brief history of China's ethnic minorities", "A series of brief chronicles of China's ethnic minority languages", "A series of books on China's ethnic minority autonomous areas", "A series of social and historical investigation materials of China's ethnic minorities". China's State Commission for Ethnic Affairs began organizing editing in 1958 and in 1991. 400 copies of the original edition were published by more than 30 publishing houses across the country.

${ }^{7}$ Chief Editorial Committee of China ethnic minority area painting series, 1986, "Collection of paintings in ethnic minority areas of China", Ethnic Publishing House.

${ }^{8}$ Gao zhanfu, 1991, "Research on the social problems of Muslims in Northwest China", ganzhen nationality press.
} 
Muslims have sponsored their own journals to introduce the latest research results, academic trends and relevant information. The types of academic journals can be divided into the following categories according to the types of sponsoring departments

\begin{tabular}{|l|l|}
\hline \multirow{2}{*}{ government office } & $\begin{array}{l}\text { The Institute of world religions of the Chinese Academy of Social Sciences sponsored } \\
\text { "STUDIES IN WORLD RELIGIONS" and "The world religious cultures"; } \\
\text { The State Administration of religious affairs sponsored the "Chinese religion". }\end{array}$ \\
\hline $\begin{array}{l}\text { Social science research } \\
\text { institutions }\end{array}$ & $\begin{array}{l}\text { Ningxia Social Sciences "Ningxia Social Sciences" and "Journal of Hui Muslim } \\
\text { Minority Studies"; } \\
\text { Gansu Institute of nationalities "Gansu Institute of nationalities"; } \\
\text { Xinjiang Social Sciences "Xinjiang Academy of Social Sciences" }\end{array}$ \\
\hline $\begin{array}{l}\text { University scientific } \\
\text { research institutions }\end{array}$ & $\begin{array}{l}\text { "The Arab world" hosted by Shanghai Institute of foreign languages; "Northwest Ethnic } \\
\text { "Qtudies" and "Chinese Hui studies" by Northwest University for Nationalities; } \\
\text { "Minghai ethnic studies" by Qinghai Institute for Nationalities; } \\
\text { "Journal of Central University for Nationalities" } \\
\text { "Journal of Northwest University for Nationalities" } \\
\text { "Journal of Northwest Second Institute for Nationalities" } \\
\text { "Journal of Yunnan University for Nationalities" } \\
\text { "Journal of Xinjiang University (literature, philosophy and history Edition)", etc. }\end{array}$ \\
\hline China Islamic Association & $\begin{array}{l}\text { "Chinese Muslims" by the China Islamic Association; } \\
\text { "Shanghai Muslim" by the Shanghai Islamic Association; } \\
\text { "Shaanxi Muslim" by the Shanxi Islamic Association; } \\
\text { "Gansu Muslim" by Gansu Islamic Association; } \\
\text { "Qinghai Muslims" by Qinghai Islamic Association; } \\
\text { "Huiwei Muslims in Hunan Province" by Hunan Islamic Association; "Xinjiang } \\
\text { Muslims" (Uygur version, Kazak version) by Xinjiang Islamic Association, etc. }\end{array}$ \\
\hline "Research on Islamic culture" sponsored by Xi'an Islamic Culture Research Association \\
\hline Songovernmental
\end{tabular}

Some of these journals, in the name of Islam and Muslims, publish research and other articles on Islam and Muslims. However, there are also religious journals, University Journals and other journals, which also publish different degrees of Islamic related papers. Among them, "STUDIES IN WORLD RELIGIONS", founded in 1979, is edited by Zhuo Xinping and vice edited by Huang xianian. It mainly publishes the academic papers of scholars at home and abroad, introduces the research trends and important materials of Religious Studies at home and abroad, and is the most authoritative academic journal in the field of Religious Studies in China. Since its establishment, it can be said that the representative position of Islamic academic journals is "Journal of Hui Muslim Minority Studies". Approved by the State Press and Publication Administration in 1990, the Quarterly Journal of Hui studies was officially established in 1991. It was originally sponsored by the Hui Islamic Institute, but in 2001 it was sponsored by the Ningxia Academy of social sciences. These journals published a large number of academic papers and related articles, which played an important role in promoting the development of domestic Islamic studies.

\section{Academic Conference}

Before the reform and development, there were few academic conferences on Islam and Muslims in China. In February 1979, the World Religion Research Institute held a national conference on religious research planning in Kunming. This conference can be seen as a new stage of the beginning of the academic conference. According to the spirit of the conference, a symposium on Islamic Studies in the five northwest provinces was held in Urumqi in 1979. The Institute of world religions agreed with the relevant institutions of the five northwest provinces to hold an annual Islamic academic seminar. 


\begin{tabular}{|c|c|c|c|c|c|}
\hline \multicolumn{6}{|c|}{ The fifth "Symposium on Islam in five provinces and regions in Northwest China" } \\
\hline Time / place & theme & host & $\begin{array}{l}\text { Number of } \\
\text { participants }\end{array}$ & $\begin{array}{l}\text { Number } \\
\text { of papers } \\
\text { and } \\
\text { materials } \\
\text { submitted }\end{array}$ & $\begin{array}{l}\text { paper } \\
\text { Selected } \\
\text { Edition }\end{array}$ \\
\hline $\begin{array}{l}\text { November } \\
\text { 10-20, } 1980 \\
\text { / Yinchuan }\end{array}$ & $\begin{array}{llll}\text { Chinese } & \text { Islam in } \\
\text { Dynasty } & & & \end{array}$ & $\begin{array}{l}\text { Ningxia Institute of Social } \\
\text { Sciences }\end{array}$ & $\begin{array}{l}\text { More than } \\
80\end{array}$ & 47 articles & $\begin{array}{l}\text { "On Islam } \\
\text { in China in } \\
\text { the Qing } \\
\text { Dynasty" }\end{array}$ \\
\hline $\begin{array}{l}\text { October } \\
\text { 10-21, 1981 } \\
\text { / Lanzhou }\end{array}$ & $\begin{array}{l}\text { Characteristics of the spread } \\
\text { and development of Islam in } \\
\text { China and its historical role }\end{array}$ & $\begin{array}{l}\text { Gansu Institute of } \\
\text { Nationalities }\end{array}$ & 151 & 65 articles & $\begin{array}{l}\text { "Islam in } \\
\text { China" }\end{array}$ \\
\hline $\begin{array}{l}\text { August } \\
18-26,1982 \\
\text { / Xining }\end{array}$ & $\begin{array}{l}\text { The characteristics of Islam in } \\
\text { China; The evolution, } \\
\text { differentiation and social } \\
\text { influence of Islamic sects and } \\
\text { officials; Ethnic Education in } \\
\text { history; Islam and ethnic } \\
\text { relations. }\end{array}$ & $\begin{array}{l}\text { Religious Bureau of Qinghai } \\
\text { Province }\end{array}$ & $\begin{array}{l}\text { More than } \\
120\end{array}$ & $\begin{array}{l}\text { More than } \\
80 \text { articles }\end{array}$ & $\begin{array}{l}\text { "Studies on } \\
\text { Islam in } \\
\text { China" }\end{array}$ \\
\hline $\begin{array}{l}\text { November } \\
\text { 22-26, } 1983 \\
\text { / Xi'an }\end{array}$ & $\begin{array}{l}\text { How does Islam serve the } \\
\text { construction of } \\
\text { civilizations }\end{array}$ & $\begin{array}{l}\text { Shaanxi Academy of Social } \\
\text { Sciences }\end{array}$ & 88 & $\begin{array}{l}102 \\
\text { articles }\end{array}$ & $\begin{array}{l}\text { "Collection } \\
\text { of studies } \\
\text { on Islam in } \\
\text { China" }\end{array}$ \\
\hline $\begin{array}{l}\text { August } \\
22-27,1986 \\
\text { / Urumqi }\end{array}$ & $\begin{array}{l}\text { History of the spread and } \\
\text { development of Islam in China }\end{array}$ & & 112 & 79 articles & \\
\hline
\end{tabular}

The "seminar on Islam in the five provinces of Northwest China" is a national academic activity with far-reaching theoretical and practical significance, which is directly related to Islam and Muslims in China and the world. However, it is a pity that the second round of Islamic academic seminar in the five northwest provinces has not been launched.

Since then, in 1983, the Symposium on Islamic literature and history along the southeast coast was held. Since the same year, the National Symposium on the history of Hui nationality has been held every two years.

In order to continue the momentum of academic development and promote the development of Islamic Studies, the World Institute of Islamic studies held three National Islamic academic seminars in Beijing from 1987 to 1990.

\begin{tabular}{|l|l|l|}
\hline time & theme & $\begin{array}{l}\text { Number } \\
\text { participants }\end{array}$ \\
\hline $\begin{array}{l}\text { August } \\
21-26,1987\end{array}$ & $\begin{array}{l}\text { The disciplinary study of the history of Islam in China, the sects of Islam in China, } \\
\text { and the development trend of Islam after the Second World War }\end{array}$ & More than 60 \\
\hline $\begin{array}{l}\text { September } \\
12,1990\end{array}$ & $\begin{array}{l}\text { Under the name of "seminar on the history of Islam in China", the theme is: how } \\
\text { Islam enriched and developed national culture after its entry into China and how to } \\
\text { accept the influence of Chinese national traditional culture }\end{array}$ & More than 40 \\
\hline $\begin{array}{l}\text { October } \\
19-21,1990\end{array}$ & $\begin{array}{l}\text { International and domestic Islamic research groups discussed the form, trend and } \\
\text { characteristics of Islam after the war; The division of Islamic stages after the war; } \\
\text { Issues related to the study of Islam in China }\end{array}$ & More than 80 \\
\hline
\end{tabular}

At the same time, since 1998, with the development of Islamic academic research in depth and breadth, a series of seminars have been held. 


\begin{tabular}{|c|c|c|c|}
\hline Meeting name & Time/place & theme & Hold \\
\hline $\begin{array}{lr}\text { Academic } & \text { seminar on } \\
\text { "Islamic } & \text { Revival } \\
\text { Movement" } & \end{array}$ & $\begin{array}{l}\text { October 25-26, } \\
1988 \text { / Beijing }\end{array}$ & $\begin{array}{l}\text { The historical background of the rise of the } \\
\text { Islamic revival movement, the profound } \\
\text { political and economic reasons, the current } \\
\text { situation and performance characteristics, } \\
\text { and the influence of the movement }\end{array}$ & $\begin{array}{l}\text { Institute of West Asia and } \\
\text { Africa, Chinese Academy of } \\
\text { Social Sciences, China Asian } \\
\text { African society and China } \\
\text { Middle East Society }\end{array}$ \\
\hline $\begin{array}{lr}\text { International } & \text { Seminar } \\
\text { on Islam } & \text { and } \\
\text { modernization } & \\
\text { construction } & \text { in } \\
\text { Northwest China } & \end{array}$ & $\begin{array}{l}\text { October 8-11, } \\
1991 \text { / Xi'an }\end{array}$ & $\begin{array}{l}\text { Islam and the foreign development of } \\
\text { Northwest China and the development of } \\
\text { Muslim nationality; Islamic Economic } \\
\text { Thought and modernization; Foreign } \\
\text { Islamic Reform Movement and } \\
\text { modernization }\end{array}$ & $\begin{array}{l}\text { Northwestern University and } \\
\text { Adenauer foundation in } \\
\text { Germany }\end{array}$ \\
\hline $\begin{array}{lr}\text { Symposium } & \text { on } \\
\text { "Islamic culture and } \\
\text { China" }\end{array}$ & $\begin{array}{l}\text { October 14-17, } \\
1991 \text { / Jinan }\end{array}$ & $\begin{array}{l}\text { The introduction of Islam into China and } \\
\text { its development process; The reasons for } \\
\text { the existence and development of Islam in } \\
\text { China; Problems encountered in the } \\
\text { dissemination and development of Islam in } \\
\text { China }\end{array}$ & $\begin{array}{lr}\text { Jinan Islamic } & \text { Association; } \\
\text { Department of } & \text { philosophy, } \\
\text { Shandong } & \text { University; } \\
\text { Shandong } & \text { Oriental } \\
\text { Philosophy } & \text { Research } \\
\text { Association } & \end{array}$ \\
\hline $\begin{array}{l}\text { International } \\
\text { Symposium on } \\
\text { "maritime Silk Road } \\
\text { and Islamic culture" }\end{array}$ & $\begin{array}{l}\text { February } \\
21-26,1994 \quad / \\
\text { Quanzhou, } \\
\text { Fujian }\end{array}$ & $\begin{array}{l}\text { The spread and influence of Islamic culture } \\
\text { in the countries along the Silk Road; } \\
\text { Friendly relations between China and } \\
\text { Muslim countries; Muslim contribution to } \\
\text { navigation and trade }\end{array}$ & 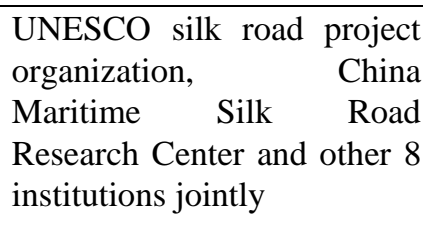 \\
\hline $\begin{array}{l}\text { Academic seminar on } \\
\text { "contemporary Islamic } \\
\text { Revival Movement" }\end{array}$ & $\begin{array}{l}\text { June 16-18, } \\
1995 \text { / } \\
\text { Ma'anshan, } \\
\text { Anhui }\end{array}$ & $\begin{array}{l}\text { The development situation of the Islamic } \\
\text { revival movement after the cold war, the } \\
\text { nature and characteristics of the } \\
\text { movement, the impact of the movement on } \\
\text { the international situation and the } \\
\text { development trend of the movement }\end{array}$ & $\begin{array}{l}\text { Middle East Research Center } \\
\text { of Shanghai Institute of } \\
\text { International Studies }\end{array}$ \\
\hline $\begin{array}{l}\text { Seminar on "Islamic } \\
\text { Arab philosophy" }\end{array}$ & $\begin{array}{l}\text { October } 9, \\
1996 / \text { Jinan }\end{array}$ & $\begin{array}{l}\text { The ideological characteristics and } \\
\text { historical influence of Islamic Arab } \\
\text { philosophy }\end{array}$ & $\begin{array}{l}\text { Department of philosophy, } \\
\text { Shandong University; } \\
\text { Shandong } r \text { Oriental } \\
\text { Philosophy research } \\
\text { Association and } \\
\text { Islamic Association }\end{array}$ \\
\hline
\end{tabular}

From 1996 to 1999, Xi'an Islamic Culture Research Association held three Islamic culture seminars in Xi'an

\begin{tabular}{|c|l|l|l|}
\hline Meeting name & time & theme & other \\
\hline "Islamic culture and real life" & 1996 & $\begin{array}{l}\text { It discusses the contemporary } \\
\text { Muslim national culture, } \\
\text { education, science and figures }\end{array}$ & $\begin{array}{l}30 \text { papers were submitted. Selected and } \\
\text { edited the treatise on Islamic culture } \\
\text { (published by religious culture). }\end{array}$ \\
\hline "Jing tang education" & 1997 & $\begin{array}{l}\text { Jing tang education, Islamic } \\
\text { Education }\end{array}$ & $\begin{array}{l}71 \text { papers were submitted. Selected } \\
\text { works of the thesis: Research on Islamic } \\
\text { culture (Ningxia people's Publishing } \\
\text { House) }\end{array}$ \\
\hline $\begin{array}{l}\text { "The 21st century and Islamic } \\
\text { culture, Islamic Studies, Islam } \\
\text { and the Chinese nation" }\end{array}$ & 1999 & $\begin{array}{l}\text { History, present situation and } \\
\text { future of Hui and Islamic culture }\end{array}$ & $\begin{array}{l}\text { More than 60 papers were submitted. } \\
\text { This paper is selected and edited as a } \\
\text { collection of Islamic culture. }\end{array}$ \\
\hline
\end{tabular}

It is the first time to comprehensively and systematically discuss and study scripture hall Jing tang education. Many papers are based on reality and discuss the economic and educational issues concerned by the Muslim public. Nearly 200 experts and scholars attended the 3rd Islamic culture seminar held in Xi'an, and 163 papers were received, which also played a positive role in promoting the study of Islam in China. Based on the topics and papers of the three conferences, 
the achievements of Islamic cultural research at that time were reflected.

Since entering the 21st century, especially in recent years, the number of conferences with the theme of Islamic research has decreased compared with the past. Conferences with the theme of Islamic and Muslim studies mainly include

\begin{tabular}{|c|c|c|c|}
\hline Meeting name & Time / place & theme & Hold \\
\hline $\begin{array}{l}\text { "Symposium on the history } \\
\text { and development of Islam in } \\
\text { China" }\end{array}$ & $\begin{array}{l}\text { December, } \\
2001 \text { / Beijing }\end{array}$ & $\begin{array}{l}\text { The history, development and future of } \\
\text { Islam in China }\end{array}$ & $\begin{array}{l}\text { Islamic Association of } \\
\text { China }\end{array}$ \\
\hline $\begin{array}{l}\text { "Seminar on the current } \\
\text { research status of Hui studies } \\
\text { and Islam" }\end{array}$ & $\begin{array}{l}\text { September } \\
21, \quad 2004, \\
\text { Yinchuan }\end{array}$ & $\begin{array}{l}\text { Research trends of Islam in Hui studies; } \\
\text { Other problems in the current study of Hui } \\
\text { Islam }\end{array}$ & $\begin{array}{l}\text { Ningxia Academy of } \\
\text { Social Sciences }\end{array}$ \\
\hline $\begin{array}{l}\text { "Seminar on Chinese } \\
\text { Scripture church education" }\end{array}$ & $\begin{array}{l}\text { January } \\
21-22,2007 \text { / } \\
\text { Lanzhou }\end{array}$ & $\begin{array}{l}\text { The development process, problems, } \\
\text { countermeasures and development } \\
\text { direction of Chinese Scripture Education }\end{array}$ & $\begin{array}{l}\text { Sponsored by Lanzhou } \\
\text { University, Institute of } \\
\text { Islamic culture, } \\
\text { Lanzhou University }\end{array}$ \\
\hline $\begin{array}{l}\text { "Symposium on } \begin{array}{l}\text { Islam and } \\
\text { building a } \\
\text { society" }\end{array} \text { harmonious } \\
\end{array}$ & $\begin{array}{l}2006 \text { 年 } 10 \text { 月 } \\
\text { October } 2006\end{array}$ & $\begin{array}{l}\text { Muslims of all ethnic groups participate in } \\
\text { building a harmonious society }\end{array}$ & $\begin{array}{l}\text { Islamic Association of } \\
\text { China }\end{array}$ \\
\hline $\begin{array}{l}\text { "Symposium on the world } \\
\text { outlook of Hui Confucianism } \\
\text { and the contemporary value of } \\
\text { Chinese Islamic research" }\end{array}$ & $\begin{array}{l}\text { June } 2011 / \\
\text { Beijing }\end{array}$ & $\begin{array}{l}\text { The world outlook of Hui Confucianism } \\
\text { and Chinese Islam are discussed from four } \\
\text { topics: literature and text, philosophy and } \\
\text { theology, civilization and culture, history } \\
\text { and reality }\end{array}$ & Peking University \\
\hline $\begin{array}{l}\text { "Symposium on Chinese } \\
\text { Islam and Chinese culture" }\end{array}$ & $\begin{array}{l}\text { December } \\
2012 \text { / Beijing }\end{array}$ & $\begin{array}{l}\text { This paper discusses Islam and Chinese } \\
\text { traditional culture from four topics: } \\
\text { literature and text, philosophy and } \\
\text { theology, civilization and culture, history } \\
\text { and reality }\end{array}$ & Peking University \\
\hline
\end{tabular}

Academic seminars with the title of Islam are rare.

These conferences attracted many scholars with their interdisciplinary theory and cross religious open vision, which promoted the development of Islamic research in China. Interdisciplinary and interreligious conferences

\begin{tabular}{|c|c|c|c|}
\hline Meeting name & Time / place & theme & host \\
\hline $\begin{array}{l}\text { "International } \\
\text { Symposium on Zheng } \\
\text { He's voyages to the } \\
\text { West and dialogue } \\
\text { among civilizations" }\end{array}$ & $\begin{array}{l}\text { June } 30 \text { to } \\
\text { July } 3,2005 \\
\text { / Yinchuan }\end{array}$ & $\begin{array}{l}\text { Zheng He made seven voyages to the west, visited } \\
\text { more than } 30 \text { countries, and launched and discussed } \\
\text { historical issues such as establishing friendly relations } \\
\text { with the people of all countries and effectively } \\
\text { promoting the economic development of all countries }\end{array}$ & $\begin{array}{l}\text { Ningxia Academy of } \\
\text { Social Sciences and } \\
\text { the Cultural Office } \\
\text { of the Iranian } \\
\text { embassy in China }\end{array}$ \\
\hline $\begin{array}{lr}\text { "Nanjing } & \text { University } \\
\text { Harvard } & \text { Yanjing } \\
\text { civilization } & \text { dialogue } \\
\text { forum" } & \end{array}$ & $\begin{array}{l}\text { June 16-18, } \\
2006 \text { / } \\
\text { Yunnan }\end{array}$ & $\begin{array}{l}\text { The global significance of dialogue among } \\
\text { civilizations; Dialogue between Hui and } \\
\text { Confucianism in China under the background of } \\
\text { globalization; East Asian knowledge in global } \\
\text { development; The global significance of indigenous } \\
\text { knowledge in Chinese Muslim society; Local } \\
\text { knowledge and cultural innovation }\end{array}$ & $\begin{array}{lr}\text { Jointly organized by } \\
\text { Nanjing } & \text { University, } \\
\text { Harvard } & \text { University } \\
\text { and } & \text { Yunnan } \\
\text { University } & \end{array}$ \\
\hline $\begin{array}{l}\text { "The } \\
\text { International } \\
\text { Symposium on Hui } \\
\text { studies" }\end{array}$ & $\begin{array}{l}\text { September } \\
3-6,2006 \text { / } \\
\text { Shahu, } \\
\text { Ningxia }\end{array}$ & $\begin{array}{l}\text { Hui studies in the global context; Dialogue between } \\
\text { civilizations and Hui Confucianism; Discipline } \\
\text { system and methodology of Hui studies; Research on } \\
\text { the history and reality of the Hui nationality in Central } \\
\text { Asia; A study on the history of communication } \\
\text { between Chinese Muslims and Muslims in Central }\end{array}$ & Chinese Hui society \\
\hline
\end{tabular}




\begin{tabular}{|l|l|l|l|}
\hline & & Asia and West Asia & \\
\hline $\begin{array}{l}\text { Symposium on } \\
\text { "religious dialogue and } \\
\text { harmonious society" }\end{array}$ & $\begin{array}{l}\text { June 5-6, } \\
2007 \quad / \\
\text { Lanzhou }\end{array}$ & $\begin{array}{l}\text { Religious dialogue and harmonious society; Multi } \\
\text { religion and harmonious society; The history and } \\
\text { present situation of Christianity in Northwest China; } \\
\text { Religious dialogue; History and present situation of } \\
\text { Islam in Northwest China }\end{array}$ & \\
\hline
\end{tabular}

\section{Collation and Publication of Reference Books and Historical Materials}

\subsection{Reference Book}

The collation of reference books and historical materials has become an extremely important link in the discipline of Islamic research. After more than 30 years, it has achieved great value and significance. This research result has been fully recognized and highly praised by the state and various departments and institutions. The proudest achievements in the research and publication of reference books are as follows:

\begin{tabular}{|c|c|}
\hline \multicolumn{2}{|c|}{$\begin{array}{l}\text { Compiled by the Editorial Committee of "China Islamic Encyclopedia": Published by Sichuan Dictionary Publishing } \\
\text { House. }\end{array}$} \\
\hline K Cata & into three parts: frontier, exampl \\
\hline $\begin{array}{l}\text { Entry classification } \\
\text { directory }\end{array}$ & $\begin{array}{l}\text { Islam, Islamic law, Islamic education, Islam, Tianfang religion, orthodox religion, Kaitian } \\
\text { ancient religion, halal religion, Islam }\end{array}$ \\
\hline $\begin{array}{l}\text { teachings derived from } \\
\text { the classics; } \\
\text { Classics }\end{array}$ & $\begin{array}{l}\text { The Koran, Haiting, Haitie, heting, fatiha, fadihai, ayeti qursi, the 18th section, the 18th } \\
\text { surai, qurat, yinzil, zahur, the name of the Koran, gurani, Fogang, mshafu, juzwu, Hizbu, } \\
\text { surai, sol, ayeti, ayat Koran chapter initials, muhakaem, mteshabih, menopause, nasih, } \\
\text { mansuhh }\end{array}$ \\
\hline Sunni Sutra & $\begin{array}{l}\text { Summary of Koran interpretation, Tiberi Sutra annotation, Razi Koran annotation, the key } \\
\text { to the mystery, Badawi Koran annotation, Ibn kesir Koran annotation, zhelalaini Koran } \\
\text { annotation, concise Koran annotation, general theory of Koran studies }\end{array}$ \\
\hline Shiite scriptures & $\begin{array}{l}\text { "Aas Carey's notes", "Jingyi Hui Jie", "Sufi school notes", "Koran note", "the quintessence } \\
\text { of the Koran", "Ruha Bellani", "Moore's Tai Chi Lai school notes", and "Kashav's notes" }\end{array}$ \\
\hline Modern classics note & $\begin{array}{l}\text { The Koran notes, the notes of the Koran, the Qur'an notes, the Koran essence, the Koran } \\
\text { essence, the Koran, the Koran, the Koran, the Koran, the Koran, the Koran, the Koran, and } \\
\text { the Koran. Rhyme translation of the Koran, Tong's translation of the Koran; } \\
\text { Color picture insert table of contents; } \\
\text { Text }\end{array}$ \\
\hline appendix & $\begin{array}{l}\text { 1. List of phonetic order of Chinese characters, 2. Stroke index of the first character of the } \\
\text { entry, 3. Chronology of Islamic personnel, 4. Genealogy of major Islamic dynasties, } 5 . \\
\text { Genealogy of twelve imams of Shia, 6. Profile of Chinese ethnic minorities who believe in } \\
\text { Islam, postscript }\end{array}$ \\
\hline
\end{tabular}

It is one of the key research projects of philosophy and social sciences during the national "Seventh Five Year Plan" period. This project has been planned, designed, organized, edited and processed since 1987. It has revised the framework system three times and compiled a book for six years. It is the first large-scale specialized reference book to comprehensively and systematically introduce the basic knowledge of Iran in China. Quan has won the second National Book Award (1995) and the first national dictionary Award (1995). ${ }^{9}$

Followed by

"Islamic dictionary" edited by Jin Yijiu

It is a medium-sized Dictionary of specialized college, and it is a research work with great difficulty in compiling. 1 Islam; 2、 Classification Glossary; 3、Body; 4、Appendix 1. The representatives of the main Muslim dynasties; 2. The Muslim Dynasty family table; 3. Shiite lineage Table; 4. and the Islamic chronology; 5、The dictionary is a medium-sized professional dictionary. It collected 3090 words and items, and it involved the history, theory and current situation of

${ }^{9}$ Compiled by the Editorial Committee of China Islamic encyclopedia,1994, "China Islamic Encyclopedia", Sichuan Dictionary Publishing House, p.773. 
Islam from 11 different aspects. The dictionary has 3090 Islamic words for readers to consult and search. This Chinese dictionary is enough to reflect the professional strength and academic level of Islamic research in China. Some people have evaluated that the dictionary is one of the popular professional tool books in China, because it has a simple and concise explanation, accurate and fluent expression, large knowledge content and wide application. ${ }^{10}$

"The religious Dictionary" (1998) has increased the number of words to nearly 12000, the number of words to about 3.7 million, and the page has been expanded to 16 pages. In order to live up to its name, the editorial board decided to change its name to the Great Dictionary of religion. Editor in chief Ren Jiyu. The book has 11970 entries. Including religion, Buddhism, Christianity, Islam, Taoism, Confucianism, etc. According to each religious system, introduce its sectarian organization, historical figures, terminology, doctrines and theology, scriptures and works, religious system and teaching posts, more expensive rituals, utensil festivals, temples, churches and gods. The information is rich and the details are appropriate. There are more Islamic entries The chapters and citations of the Koran are based on Ma Jian's translation of the Koran by China Social Sciences Press. ${ }^{11}$

There is also "The Islamic Dictionary" (2001), which has 1932 entries for the convenience of professionals. ${ }^{12}$

Related to it, "The religious dictionary" was published in 1981, with a total of about 7000 entries. Including Buddhism (including Tibetan Buddhism), Christianity (including Catholicism, orthodox and Protestantism), Islam, Taoism, some ethnic minority religions in China, Chinese folk religions, other religions, etc. This is the first religious book published in New China. At that time, it met the needs of society and attracted the attention of academic and religious circles at home and abroad. When compiling this dictionary, There are two shortcomings: first, some of the materials used were slightly old and failed to reflect the religious situation and research results in time; Second, the religious categories collected are not complete and need to be supplemented. Therefore, after the publication of the religious dictionary, preparations for revision and supplement will be made. ${ }^{13}$

Research data index, thesis index and written index of ancient books include "Brief list of Chinese Islamic thesis data (1949-1980)", "Important materials such as bibliographic index of ancient Islamic books in Xinjiang" and "Index of Hui research materials".

\subsection{Collection and Arrangement of Historical Materials}

In recent years, a prominent achievement in the study of Islam in China is the collection and sorting of historical data. This work goes hand in hand from two aspects. On the one hand, it collects and arranges the rare historical materials of Chinese Islam from the overall perspective; The other is the compilation of local Islamic history materials. Scholars pay more and more attention to the data sorting and rescue of Islam in China.

In 1994, Ma Baoguang edited "The series of Chinese Hui classics", which was published as internal materials. The series contains 21 kinds of Islamic Chinese classics, which are translated in both Ancient and modern Chinese. It is divided into 6 volumes with about 3.5 million words. This is a large set of vernacular translations of ancient books. It is a difficult work in the collation of ancient books, which needs a deep research foundation. ${ }^{14}$

In 1998, the office of the planning group for the collation and publication of ancient books of ethnic minorities in Ningxia photocopied and published the first volume of "the compilation of ancient books of Hui and Chinese Islam", which included 15 kinds of early Chinese Islamic documents, divided into 9 letters and thread bound. This is also a large collection of photocopies of ancient books. ${ }^{15}$

The representative achievements that must be mentioned in these aspects are: "Selected reference articles on the history of Islam in China (1911-1949)", compiled by Li Xinghua and Ma Jinyuan, and published in 1985. The book contains 197 papers, investigations, essays, reports and translations on the history and culture of Islam in China scattered in Chinese newspapers and series, with more than one million words. The selected Edition enables scattered data to be systematically and comprehensively collected and sorted, saves a number of historical documents, and provides rich reference materials

\footnotetext{
${ }^{10}$ Jin Yijiu (edited), 1997, “Islamic dictionary”, Shanghai Dictionary Publishing House, p.771.

${ }^{11}$ Ren Yuji (edited), 1998, "religious dictionary", Shanghai dictionary press.

${ }^{12}$ Jin Yijiu (edited), 2001, "little dictionary of Islam”, Shanghai Dictionary Publishing House, p.1(directory).

${ }^{13}$ Ren Yuji (edited),1981, “The religious dictionary”, Shanghai Dictionary Publishing House.

${ }^{14}$ Ma Baoguang (compiled), 1994, "Chinese Hui Classics Series”, (internal data).

${ }^{15}$ Ningxia minority ancient prose collation and publication plan, 1998, "The compilation of ancient books of Hui and Chinese Islam", Tianjin Ancient Books Publishing.
} 
for researchers. ${ }^{16}$

Yu Zhengui and Yang Huaizhong collected 580 ancient and modern documents and books, "Compiled them by classification and wrote abstracts". They made a systematic summary of Islamic literature before 1992, which is very useful. 17 "Chinese Hui ancient books series" (Ningxia minority ancient books sorting and publishing planning group, 2000).Publication Preface: "In order to save and preserve the historical materials of the Hui nationality", it is decided to systematically collect materials and word-of-mouth materials in Chinese, Arabic, Persian and other texts related to the history of the Hui nationality throughout the country, including historical classics, biographies, genealogies, literature inscriptions, representative Islamic materials Menhuan sect materials and modern Hui newspapers and periodicals. The number of years of data received began in the Tang and Song Dynasties and ended before the founding of the people's Republic of China in 1949. ${ }^{18}$

With the subsequent publication of "The series of Chinese Hui ancient books", more new materials or rare and unique documents will be dedicated to researchers. "Qingzhen ceremony", which is subordinate to "The collection of Chinese religious historical documents". ${ }^{19}$

"The collection of Chinese religious historical documents" is the first large-scale photocopy ancient book series in China that collects the historical documents of major religions in China. The book has a total of 180 volumes, which is divided into five parts: "Buddhism outside Tibet", "The collection of three caves", "the Qingzhen Scripture", "The eastern Gospel" and "The folk treasure volume", It contains more than 1100 kinds of religious classics, inscriptions and documents from the past dynasties to the beginning of the 20th century.

In the collection of Chinese religious historical documents, "Buddhism outside Tibet" and "three cave collection" only collect Buddhist and Taoist documents outside Tibet, while the folk scroll also contains literary scroll, while the Qingzhen canon and the eastern gospel are the first systematic and comprehensive compilation of historical documents of Islam and Christianity (including Catholicism, Protestantism and Orthodox). All collections are collected from domestic universities, public libraries and museums, most of which are rare and isolated books on the verge of loss, or important documents and materials published for the first time. This book is the first comprehensive and systematic collation of Chinese Islamic documents and classics, including nearly 200 kinds of important documents, about 25 million words, which are stored in 25 volumes respectively. It not only includes the earliest engraved version of the Koran in Chinese history, the precious copy of the Koran in the Qing Dynasty and the copy of the Hui astronomical calendar in the Ming Dynasty, but also publishes some important folk copies that were often ignored in the past, such as compendium for the first time, some of which belong to rescue sorting. It has laid a solid foundation for the later study of Islam in China, and its importance is self-evident. The academic circles have given a very high evaluation of the great canon, such as "the view of documents compiled in this book covers a wide range from scripture translation to minor miscellaneous studies, from doctrinal interpretation to enlightenment reading, from astronomical calendar to medical drugs, from etiquette and law to Sufism, from historical and geographical records to inscriptions and local chronicles, It significantly reflects the depth and breadth of the combination of Islam and Chinese social culture For understanding the spread, development and evolution of Islam in China and correctly understanding the relationship between religion and nationality, especially the relationship between Islam and all ethnic groups in China who believe in Islam; Explore the characteristics of Islamic culture, especially the communication and integration of Islam with China's main society and mainstream ideas, the hard efforts made by Muslim scholars in history, and contribute to promoting the discipline construction of religious teaching, writing the history of Chinese religion, the history of Chinese Islam, the history of Chinese ethnic relations, the history of Chinese Hui nationality, the history of Chinese thought and the history of cultural exchanges between China and foreign countries, All have irreplaceable value. "20

Another research achievement in this regard is "The collection of Hui history" (1984), which contains 60 research papers from 1949 to 1979 , with a catalogue index of Hui history research papers in the same period, which provides convenience for researchers.

\footnotetext{
${ }^{16}$ Li Xinghua, Ma Jinyuan (edited), 1985, "Selected references to the history of Islam in China (1911-1949)", Ningxia people's publishing house, 2 books.

${ }^{17}$ Yu Zhengui, Yang Yizhong, 1993, “Abstracts on the writing and translation of Chinese Islamic Literature”, Ningxia people's publishing house, p.65.

${ }^{18}$ Ningxia minority ancient books sorting and publishing plan, 2000 "Chinese Hui ancient books series", p.1(Preface).

19“Islamic halal ceremony", was recorded in "the Integration of Chinese religious history documents", Huangshan publishing house, 2006.
}

${ }^{20}$ Zhou xiefan, 2006, "preface to the halal ceremony", research on world religions, Vol.2,pp. 147-148. 


\begin{tabular}{|l|l|l|}
\hline $\begin{array}{l}\text { Important local } \\
\text { data sets include }\end{array}$ & $\begin{array}{l}\text { "Xinjiang religious research materials"; "Abstract of historical materials of Ethnic Religion in } \\
\text { Northwest China"; "Selected materials of Quanzhou Hui genealogy" } \\
\text { "Historical materials of Xidaotang"; "Historical materials of the Hui nationality in Sadian" }\end{array}$ \\
\hline $\begin{array}{l}\text { Historical data } \\
\text { investigation } \\
\text { report }\end{array}$ & $\begin{array}{l}\text { "Tuomao people in Qinghai and their relationship with Islam"; "Investigation on the social history } \\
\text { of Hui nationality in Yunnan"; "Investigation on Islam in Kashgar and Hotan areas of Xinjiang"; } \\
\text { "Investigation on Yichan and Wahhab sects of Islam of Uygur nationality in Xinjiang" }\end{array}$ \\
\hline $\begin{array}{l}\text { Excavation and } \\
\text { arrangement of } \\
\text { ancient books }\end{array}$ & $\begin{array}{l}\text { "Biography of the Department of Confucian classics"; "Beijing Niu Jie Zhi Shu - Gang Zhi"; } \\
\text { "Kremer's interpretation of enlightenment"; "Kublinye pedigree of Islam in China -- dawantau } \\
\text { official"; "A brief history of Chinese Islam"; "A collection of the history of zehringer's } \\
\text { orthodoxy"; "Taizi Gongbei Ma Ming and Qing Dynasties sages wear a brief"; "Halal roots"; } \\
\text { "Saidianchi genealogy" } \\
\text { "Ganjiaopu family tree in Nanhai"; "Selected genealogies of Hui nationality in Liaoning"; } \\
\text { "Record of accumulated stones"; "Quanzhou Islamic religious stone carvings"; "Selected edition } \\
\text { of Hebei halal steles, plaques and couplets" }\end{array}$ \\
\hline
\end{tabular}

The excavation and sorting of precious documents has opened up a new field for the study of Islam in China and promoted the in-depth development of the research work. In addition, there are similar work.

"Selected papers on Quanzhou Islam" compiled by Quanzhou Overseas Transportation History Museum and Quanzhou History Research Association (Fujian people's publishing house, 1983); Ningxia people's Publishing House and Fujian people's publishing house jointly published "Quanzhou Islamic stone carvings" (1984) compiled by Quanzhou Overseas Transportation History Museum; "Research on Islamic monuments in Guangzhou", compiled by Ma Jianchuang, etc. (Ningxia people's publishing house, 1989); Da Zhenyi and An Yonghan, editor in chief, "selected inscriptions of the Hui nationality in southern China". (Ningxia people's publishing house, 1999) etc.

Great progress has also been made in the comparison, collation and publication of ancient Chinese books. Etc. Liu Zhi,Ma Zhu,Wang Daiyu,Ma Fuchu,Li Yanxiang,Zhao can,maberliang, dapson's books.

These results show that there will be more and larger achievements in the collation and publication of ancient books soon. Moreover, the digitization of books and materials is also being carried out quietly. The database construction of the Institute of world religions of the Chinese Academy of social sciences may be the fastest in terms of the major of Islamic research. I believe it will bring a qualitative leap to the research work in the near future.

It should also be mentioned that "The examination of Islamic Chinese books" translated by Yang Daye has a high academic level and has great reference value for the study and collation of Islamic Chinese classics. The original author Leslie (Li Dunan) is an Australian Sinology expert, specializing in the Chinese Islamic classics in the late Ming and early Qing Dynasties. Because he mastered many languages and was good at textual research, his analysis and conclusions had a credible basis.

The first book of the series was published in 2001. Yu Zhengui and Lei Xiaojing edited the record of Chinese Hui gold and stone. The book compiles 440 valuable inscriptions since the Yuan Dynasty, including 10 aspects

Create, rebuild and repair mosque inscriptions, doctrines and doctrines, history of religion, merit and virtue monuments, donation and student aid inscriptions, notice inscriptions of prohibition and negotiation, character inscriptions, religious dispute plan inscriptions of clan rules and religions, Muslim cemetery inscriptions, etc

\section{Results}

The main purpose of this research is to summarize the research process and achievements of modern Islam and Muslims in China from the perspective of academic history, so as to provide experience summary and lay a starting point for today's people who are trying to engage in Islamic research. The second is to provide the later scholars with the literature of Islamic Studies in this period. On the other hand, its more profound significance is to enable scholars to fully realize that combing and summarizing the existing academic achievements is an indispensable key link in the research process, so as to enhance the awareness of academic history research and establish the norms of academic research.

\$The research object of this subject is not only limited to the research results in the religious field of Islam, but also in the research field of history, philosophy, politics, society and culture of Islam. It makes a systematic analysis of the research trends in each period and each stage. 2 China's research achievements on Islam and Muslim issues include: field research report, literature research, translation research, folk research, etc. what the author can do is to try his best to collect all the works and related materials of the research object as far as possible, classify and summarize them, read and understand them word by word, then analyze and synthesize them, try to express what they think. 3Systematic, comprehensive and 
in-depth research on the basis of collection, collation and analysis. According to the author's current situation, he has no ability to creatively put forward new ideas recognized by the academic circles, but what he wants to do is to try to answer the overall characteristics of China's research on Islam through comprehensive collection, collation and analysis of data.

The academic history of Islam in China. It not only refers to the academic history of Chinese scholars' research on Chinese Islam, but also includes the carding of various researches and achievements of Chinese scholars on foreign Islam and Muslims. This includes the study of Islamic classics such as Koran and hadith, history, pedagogy, philosophy, politics, society and culture. Islam and Muslims in different regions of foreign countries also have different characteristics, and the research methods also respect this aspect of attention.

On the origin of academic history: according to the author's own and previous research results, it can be concluded that academic research with contemporary significance began at the beginning of the 20th century. Under the background of the introduction of Western learning to the East, modern academic research methods also affected the research field of Islam in China. There are four imams with high academic level, such as Ha Decheng, Wang Jingzhai, Da Pusheng and Ma Songtin. There are also Chen Hanzhang, Chen Yuan and Chuan Tongxian non-Muslim scholars joining the ranks of Islamic researchers. There was little research before the 20th century.

The year 2000 can be regarded as the dividing line in the evolution of modern Islamic academic history. The period from the beginning of the 20th century to the founding of new China can be regarded as the beginning period. The period from the founding of new China to the reform and development can be regarded as the initial period. During this period, due to various political movements and other reasons, China's Islamic academic history and many other fields suffered setbacks such as stagnation to varying degrees. The period from reform and development to 2000 can be regarded as the prosperous period of Islamic academic research in contemporary China. Islam research is not only a religious research task, but also a cultural phenomenon, from the political, social, economic and even information science perspective. During the period from 2001 to now, the subject consciousness is clear and the research methods are diversified. Many industries and scholars have actively participated in this research field, that is, using the theories and methods of religion, ethnology, anthropology, sociology, history, philosophy, linguistics, culture, politics and other disciplines to systematically study the historical, political, economic, cultural and other phenomena of Islam and Muslims, so as to lay a foundation for the further development of China's Islamic research.

\section{Acknowledgements}

I am immensely grateful for the research environment provided by Tohoku University of Japan, in particular the Frontier Research Institute for Interdisciplinary Sciences, and the teachers and administrators of the Institute. I especially want offer thanks to Prof. Toshiyuki Hayase (Director of the Frontier Research Institute for Interdisciplinary Sciences, Tohoku University) and Prof. Takashi Kuroda (Graduate School of International Cultural Studies, Tohoku University). Thanks, are also due to the Faculty of Oriental Studies, University of Oxford, in particular, Prof. Christopher Melchert. This project would not have been completed without the Faculty's help and support.

This work was supported by "Leading Yong Researcher Overseas Visit Program" (Tohoku University, JAPAN), February 1, 2020 to January 31, 2021(one year), Research University: University of Oxford (Faculty of Oriental Studies).

\section{References}

"China's ethnic minorities", "A series of brief history of China's ethnic minorities", "A series of brief chronicles of China's ethnic minority languages", "A series of books on China's ethnic minority autonomous areas", "A series of social and historical investigation materials of China's ethnic minorities". China's State Commission for Ethnic Affairs began organizing editing in 1958 and in 1991.

"Islamic halal ceremony", was recorded in "the Integration of Chinese religious history documents", Huangshan publishing house, 2006.

Bai, S. Y. (2000). A brief history of Chinese Islam. Ningxia people's publishing house.

Biography of the western regions in the history of the Ming Dynasty.

Chen, H. Z. (1926). History of Chinese Islam. Historiography and geoscience, 1, 16-22.

Chen, T. (1927). A brief introduction to the history of Islam in China", the first edition of the monthly journal of Sinology of the Institute of Peking University, 25(1), and the later edition of the Oriental journal, 25(1), 1928.

Chief Editorial Committee of China ethnic minority area painting series, 1986, "Collection of paintings in ethnic minority areas of China", Ethnic Publishing House.

Compiled by the Editorial Committee of China Islamic encyclopedia,1994, "China Islamic Encyclopedia", Sichuan Dictionary Publishing House.

Gao, Z. F. (1991). Research on the social problems of Muslims in Northwest China. ganzhen nationality press. 
Jin, Y. J. (edited). (1997). Islamic dictionary. Shanghai Dictionary Publishing House.

Jin, Y. J. (edited). (2001). little dictionary of Islam. Shanghai Dictionary Publishing House.

Li, X. H., \& Ma, J. Y. (edited). (1985). Selected references to the history of Islam in China (1911-1949). Ningxia people's publishing house, 2 books.

Ma, B. G. (compiled). (1994). Chinese Hui Classics Series”, (internal data).

Ningxia minority ancient books sorting and publishing plan, 2000, “Chinese Hui ancient books series", Ningxia People's Publishing House.

Ningxia minority ancient prose collation and publication plan, 1998, "The compilation of ancient books of Hui and Chinese Islam", Tianjin Ancient Books Publishing.

Ren, Y. J. (edited). (1981). The religious dictionary. Shanghai Dictionary Publishing House.

Ren, Y. J. (edited). (1998). religious dictionary. Shanghai dictionary press.

Sha, Z. P. (2004). Chinese Islamic Studies. Peking University Press.

Yu, Z. G., \& Yang, Y. Z. (1993). Abstracts on the writing and translation of Chinese Islamic Literature. Ningxia people's publishing house.

Zhou, X. F. (2006). Preface to the halal ceremony. Research on World Religions, 2, $147-148$. https://doi.org/10.1179/kiv.2006.72.2.001

\section{Copyrights}

Copyright for this article is retained by the author(s), with first publication rights granted to the journal.

This is an open-access article distributed under the terms and conditions of the Creative Commons Attribution license which permits unrestricted use, distribution, and reproduction in any medium, provided the original work is properly cited. 